\title{
THE WTO'S APPELLATE BODY: LEGAL FORMALISM AS A LEGITIMATION OF GLOBAL GOVERNANCE
}

\author{
Sol Picciotto \\ (forthcoming in Governance, vol. 18, issue 3, summer 2005)
}

\begin{abstract}
The creation of the Appellate Body (AB) of the WTO entails an unprecedented delegation of power to an international adjudicator, since the WTO requires states to ensure compliance of their domestic regulations with the sweeping obligations in WTO agreements. This is legitimized in some academic analysis and much political rhetoric in terms of the rule of law, suggesting that the role of the adjudicator is merely to apply the precise words of the texts agreed by states, according to their natural meaning. The AB has supported this, by adopting a formalist approach which combines an objectivist view of meaning with a legalistic style of judgement. However, both the general structure and many of the specific provisions of the WTO agreements are indeterminate and raise issues of interpretation which were known to be highly contestable. Although the delegation of adjudication in its early phase was considered to be of a narrow technical function, in the current phase interpretation is more clearly seen to involve a flexible application of principles to cases in the light of the policies involved. The $\mathrm{AB}$ 's role would be better legitimized by adopting a more open epistemology and reasoning which could be accessible to a wider constituency. However, it is constrained by fear of usurping the political legitimacy of the governments to which it is primarily accountable, and they in turn are motivated by a reluctance to admit to their domestic constituencies how much power has been transferred to supranational instances such as the AB.
\end{abstract}

\section{INTRODUCTION}

\section{The WTO's Appellate Body and the Legalization of Global Governance}

The World Trade Organization (WTO) has quickly become the most prominent, powerful, and controversial institution of global economic governance, due not least to its system of dispute-resolution. The political acceptability of compliance with the wide range of WTO obligations rests essentially on the legitimacy of the quasi-judicial form of the WTO's dispute settlement procedure, and principally its Appellate Body (AB).

The WTO agreements place extensive obligations on states to ensure that their national economic regulations comply with WTO standards, covering matters ranging from product technical and safety requirements to intellectual property rights, aids to industry and treatment of foreign investors, and corporate taxation. ${ }^{1}$ The $\mathrm{AB}$ hears appeals on points of law from decisions made by Panels on complaints by states under all the WTO agreements;

\footnotetext{
? Lancaster University Law School, s.picciotto@lancs.ac.uk. I would like to thank the editors of this special issue, who also organized the two workshops which provided a rich environment to clarify and refine the ideas, as well as the two anonymous referees, and as ever Catherine Hoskyns, for stimulating conversations, careful textual comments and much else besides.

${ }^{1}$ Full details of all the disputes and texts of the Reports, as well as an Analytical Index - Guide to WTO Law and Practice are available on the WTO website www.wto.org.
} 
unlike the Panels, which are chosen ad hoc, the AB is a standing institution composed of seven members appointed for a 4-year term, renewable once. The major innovation under the WTO is that AB reports must automatically be adopted unless the Disputes Settlement Body, composed of member state representatives, unanimously overturns the $\mathrm{AB}$ report. This reverses the GATT rule which needed a positive decision to adopt reports made by panels that included the disputing parties, giving governments a power to block adverse rulings. Hence the creation of the $\mathrm{AB}$ and its powers represents a major delegation of power to a quasi-legal body.

The role of the $\mathrm{AB}$ must seen within the broader context of the legalization of world politics (Goldstein, Kahler, Keohane and Slaughter), and especially of global economic governance in which the WTO is a central institution (Picciotto 2003). An influential group of commentators has suggested that the WTO rates highly on a spectrum of the extent of legalization according to three criteria: being based on rules which are regarded as binding, which are precise, and the interpretation of which has been delegated to a third party adjudicator (Abbott, Keohane, Moravcsik, Slaughter and Snidal, 404-6). This has been criticized as taking a narrow view of law (Finnemore and Toope). The present paper will take such criticism further, focusing in particular on the proposition that law provides relatively precise rules, which rests on the view that legalization entails political decisions by states to make 'credible commitments', the application of which they delegate to adjudicators operating within a formalist rationality (Abbott and Snidal, 426-7).

Undoubtedly, the WTO agreements lay down an enormous quantity of legally-binding rules, the interpretation of which has been delegated to the $\mathrm{AB}$ as an adjudicator. However, the suggestion that these rules are precise and unambiguous is highly dubious. The paper shows that both the general structure and many of the specific provisions of the WTO agreements raise issues of interpretation which were known to be highly contestable, and indeed were being contested, in the period when the texts were negotiated and agreed. They have been described as 'trip-wire texts' which reflect diplomatic fudges by negotiators, so that cases referred for adjudication under them are likely to be politically charged (Alter, 793).

The location and role of adjudication in institutions for global governance raises a number of issues which in many ways make accountability problematic. Since the primary units within the classical liberal international system are considered to be sovereign states, delegation of decision-making power over regulation to an adjudicator is politically problematic. Older forms of international coordination, mainly reliant on treaties between states, are supplanted by more complex networks of regulation which combine different types of norms - 'hard' and 'soft' law (Shelton; Abbott and Snidal). Although the combination introduces a desirable flexibility and adaptability of the normative frameworks, the formally binding rules still require agreement between governments through diplomatic negotiations, and hence are unavoidably relatively rigid. The increasing complexity of regulatory issues raised by the management of a globalized economy further enhances the role for an adjudicator tasked with interpreting and applying agreed general rules to more specific instances.

These issues relate to broad questions about the characteristics of the new global governance and the role of law within it. Legalization has been an important feature of the management of economic globalization. Under a formalist view of law, legitimacy is thought to be provided by law because it offers a process for decision-making which is technical-rational: a logical application of precise or unambiguous rules prescribing obligatory conduct, to implement politically-determined aims (Abbott et al.). Yet the interpretation and application of legal rules is not a mechanistic but a flexible process, which allows scope for the overt or 
covert consideration of social, political and cultural factors, and adaptation to circumstances. Law provides a possibility to help to accommodate the diversity of local and national social and cultural particularities to the increasingly globally integrated world market, and to manage conflicts resulting from power disparities (Picciotto 1997, 266). However, its success depends significantly on the form of legal approach adopted, which in turn results from the institutional design, in particular the relationship of the legal processes and actors to the various political bodies to which they are accountable.

The issues of legalization, the use of law and the accountability of adjudicators are explored through a discussion of the history of the emergence of dispute-settlement (DS) under the GATT, as well as the experience of the first eight years of the existence of the AB (19952003) and current debates about it. The article focuses in particular on the question of formalism as reflected in both the procedures and the discourses developed by the $\mathrm{AB}$ as an adjudicative organ. This also has a broader relevance to the issue of formalism and technicism of other kinds of governance bodies performing delegated public or state functions.

\section{Formalism and Technocratic Legitimacy}

Like the other forms of delegation discussed in this collection of papers, the creation of the $\mathrm{AB}$ entails a transfer from political bodies (governments) to a relatively autonomous public body of a specific task seen as a technical one. In the traditional Weberian perspective on technocracy this is seen as a means merely of implementing policies which have been formulated through political processes. From this viewpoint, the growth of delegation to nonmajoritarian regulators is a response to the problems of governing increasingly complex societies, by giving greater autonomy to technocratic decision-makers within a policy framework set by government.

However, it has also been seen as reflecting changes in the nature and relationship of the 'public' sphere of politics and the 'private' sphere of economic activity (Kooiman; Rhodes; Pierre). Even the term 'non-majoritarian' suggests that in many ways the transfer also reflects changes in political processes, with the breakdown of representative government based on party-democracy, and the emergence of what Bernard Manin has called 'audience democracy', and hence the need to insulate greater areas of decision-making from influence by special interests. ${ }^{2}$ This in turn poses the question of whether the decentralization or fragmentation of hierarchical government based on formal or instrumental rationality, and the shift to networked governance requiring reflexive interactions and based on communicative rationality, may offer a basis for new forms of deliberative or discursive democracy (Dryzek 1990, 1999). Central to this are questions about the nature of technocratic governance and the basis of its legitimacy.

My thesis is that the degree of formalism displayed by a technical decision-making body such as the $\mathrm{AB}$ depends on its confidence in its political accountability. Global decision-makers such as the $\mathrm{AB}$ confront an accountability dilemma. In formal terms they are established by states and therefore accountable to national governments for the powers delegated to them.

\footnotetext{
${ }^{2}$ Thus, it has been argued that the role of WTO rules and their adjudication by the AB is to ensure by 'the regular application of determinate rules' that states live up to free trade obligations and resist interest group pressures which dominate national political processes (McGinnis and Movsesian, 568).
} 
This implies a formalist approach to legal adjudication, seeing it as requiring only the application of the rules in the texts according to their clear and natural meaning. A formalist approach deploys a closed epistemology, based on an objectivism which treats the abstract concepts in the texts through an instrumental rationality, resulting in decisions expressed in legalistic terms.

This closure tends to exclude debate about the values involved in the interpretive choices made by the adjudicator, which would entail acceptance of a more extended and direct accountability to a broader political constituency, rather than through national governments. It is also technicist (taking its specialist part for the whole), since its closed rationality excludes reflexive dialogue with those outside its closed epistemological sphere. The accountability dilemma of the $\mathrm{AB}$ is reflected in the reasoning shown in its decisions, which are generally expressed in legalistic terms, but astutely tread a difficult political line aimed at ensuring their acceptability to its various constituencies.

However, adjudication entails interpretation of the texts which specify the rights and obligations of parties who choose to refer their disputes to the adjudicator. Such texts are inevitably somewhat indeterminate, for several reasons. At the most basic level, language is open-textured, and words cannot be regarded as having an inherent, fixed meaning. In postWittgensteinian theories, meaning is seen as constructed and dependent on conventions and shared understandings within an interpretative community. Abstract general principles such as legal rules cannot be mechanically applied, as claimed by objectivist views of meaning. Inductive-deductive reasoning requires the adjudicator to decide how they apply to the specific case presented for decision, and in turn to give reasons for that decision, also expressed in general terms. More particularly, legal rules are normative, and hence their interpretation inevitably involves judgements about values. ${ }^{3}$ For example, Canada's challenge in the WTO to the French ban on products containing asbestos ${ }^{4}$ hinged first on whether it breached the GATT rules on non-discrimination between 'like products', which entailed a judgement on whether items such as building products containing asbestos fibre are 'like' those containing cellulose and glass fibres, and then whether the ban was `necessary to protect ... human life or health'. It is hard to maintain that these issues can be decided by relying simply on the literal meaning of the words in the texts.

Formalism is also used as a defence against charges that the delegatee has exceeded its powers, since it denies that the adjudicator has any policy-making role. However, since it produces reasoning which is closed and coded, intelligible only to insiders, it may indeed provide a cloak for activist decision-making. However, a greater degree of openness by an adjudicator about the policy implications and the value preferences entailed in the interpretative choices requires a high degree of confidence in the adjudicator's institutional

\footnotetext{
${ }^{3}$ Abbott et al. base their view that law entails a degree of precision explicitly on the positivist theory of law of H. L. A. Hart, and particularly his discussion of the core meaning and the 'penumbra' of legal rules. However, this was famously criticized by Lon Fuller, who argued that legal precepts are not merely statements of a general character but norms, so that interpreting their meaning when applying them to particular cases entails a normative judgement, and this is not limited to the 'penumbra' of borderline or doubtful cases, but that every application of a general rule to a particular case involves purposive interpretation. He also criticized Hart's 'pointer theory of meaning', and referred to Wittgenstein, Russell and Whitehead.

${ }^{4}$ European Communities - Measures Affecting Asbestos and Asbestos-Containing Products (WT/DS135/AB/R, 12 March 2001).
} 
role and accountability. Thus, I suggest that formalism stems from difficulties in the institutional design, involving inadequate or unclear accountability. This in turn is due to the more fundamental dilemma of whether accountability via governments to national state political structures is adequate to legitimise the extensive regulatory powers now delegated to global governance institutions.

\section{The Free Trade`Constitution’ AND THE ROLE OF THE AB}

The $\mathrm{AB}$ is the most prominent element in the extensive legalization of the management of international trade represented by the package of agreements which established the WTO. The WTO agreements place extensive obligations on states to ensure that their national economic regulations comply with WTO standards. To ensure compliance with this broad sweep of commitments, the WTO agreements give its DS system very extensive powers to decide whether national regulation complies with a wide variety of international standards, ranging from product technical and safety requirements to intellectual property rights, aids to industry and treatment of foreign investors, and corporate taxation. ${ }^{5}$ Initially an institutionalized system of political-diplomatic mediation (Dam), it became transformed under the GATT into a form of arbitration (Hudec 1975, 1993). In the WTO, the Panels and $\mathrm{AB}$ constitute a full-blown trade court in all but name, although its history and institutional location create a continuing tension between diplomatic and judicial approaches (Weiler).

The DS procedure entails a very significant delegation of power upwards, from national states to a supranational body. The AB's decisions take the form of reports to the Dispute Settlement Body (DSB), which is generally responsible for the DS system. The DSB is composed of government representatives and has the power to make recommendations and rulings (provided they do not alter rights or obligations under the agreements) aimed at resolving matters raised by states. However, the major innovation under the WTO is that AB reports must automatically be adopted unless there is a political consensus in the DSB against. This reversed the GATT rule which needed a positive decision to adopt DS reports by the state representatives (including the disputants), giving governments a power to block adverse rulings. States are required to implement the decisions within a reasonable period, by bringing their domestic regulations into line. If they fail to do so, the complainant may request 'mutually acceptable compensation', in the absence of which it may request authorization from the DSB for the suspension of concessions in relation to the recalcitrant state - in effect trade sanctions. This makes the $A B$ unusual as an international body whose decisions are backed by significant powers to ensure implementation.

The content of this delegation is also very significant, in that it confers a power to review any national laws and regulations which another party complains are not compatible with the very extensive regulatory requirements of the WTO agreements. An adverse ruling by the AB means that the state must rewrite its domestic regulations. This raises important issues of both legitimacy and accountability. The AB's power to review the validity of national regulations allows it in effect to overrule even laws enacted by legislatures. This in turn raises the issue of accountability. The primary actors in international trade disputes are the executive branches of governments, who decide when to bring complaints against others and are

\footnotetext{
${ }^{5}$ Full details of all the disputes and texts of the Reports, as well as an Analytical Index - Guide to WTO Law and Practice are available on the WTO website www.wto.org.
} 
responsible for defending those brought against themselves. ${ }^{6}$ However, decisions of the AB should also indirectly be addressed to the legislatures, since they must be persuaded to amend or withdraw national regulations found to be non-compliant. ${ }^{7}$ The legitimacy of the adjudications is indeed crucial, since trade countermeasures are a last resort and at best a blunt instrument. ${ }^{8}$ Beyond the legislatures, the AB's decisions need the legitimacy of acceptability to the various constituencies or the general public represented by the legislators.

This broadening of accountability has occurred to some extent, especially in the USA, and more recently the EU, who have been the main players in WTO disputes. ${ }^{9}$ US trade policy is conducted by the US Trade Representative (USTR), an executive office established in 1962. It was made a Cabinet-level agency in 1974, with the responsibility of monitoring and taking action against barriers to US exports, for which since 1988 it has direct responsibility and must report to Congress. ${ }^{10}$ These provisions establish procedures for US firms and industry associations to file petitions on which the USTR must act. The European Commission later followed the US in introducing procedures encouraging business interests to bring complaints, as part of the Market Access Strategy launched in 1996, aiming to take the offensive in response to the spate of WTO complaints launched by the USA (Shaffer, 94101). At the same time, this procedure gives the European Commission in handling complaints greater autonomy vis-à-vis the Member States, which otherwise must authorize Commission action through the 'article 133 Committee'. ${ }^{11}$

\footnotetext{
${ }^{6}$ In the WTO only states may bring complaints. This may be contrasted not only with EC law, which can directly be invoked by private persons, but also investment treaties, which have increasingly given foreign investors (mainly firms) the right to refer claims to international arbitration. Thus, under chapter XI of the NAFTA a number of claims have been brought by firms alleging breach of their investment treaty rights by national regulations (see Tollefson; Shapren).
}

${ }^{7}$ The WTO Agreement, art. XVI.4, requires each member state 'to ensure the conformity of its laws, regulations and administrative procedures with its [WTO] obligations'. However, WTO rules are not generally considered to be `supranational', i.e. to have direct effect as national law (Matsushita, Schoenbaum and Mavroidis, ch.5).

${ }^{8}$ They can be only prospective and do not compensate for lost trade; they are also counter-productive in damaging trade. Even if the countermeasures may be carefully targeted at the recalcitrant state's domestic firms, this is often difficult given the extent of internationalization of business networks, and the victims are likely to be sectors dominated by smaller firms, which may be less able to influence legislatures: see generally Charnovitz.

${ }^{9}$ In the first 8 years, to the end of 2002, they had between them been involved as complainant in $48 \%$ of the 276 disputes formally initiated, and as defendant in $41 \%$ (Leitner and Lester, 253), and have joined other disputes as interested third parties.

${ }^{10}$ Thus, Congress can interrogate the USTR and hence challenge trade policy decisions, while it cannot do so for the President; the Congress provides an important avenue for business lobbies to pressurize the USTR (Shaffer, 38-40).

${ }^{11}$ Under article 133 (formerly 113) of the EC Treaty, the Commission conducts international commercial negotiations under an authorisation from and in consultation with a special committee appointed by the Council. The TBR procedure allows a firm (if supported by the Commission) to override political opposition by a blocking minority of Member States in the article 133 Committee. Thus, a complaint by German aircraft manufacturer Dornier, against Brazil's export financing scheme as applied to aircraft, was brought under the TBR since after informal inquiries the Commission could see that there would be opposition in the article 133 Committee from member states with firms acting as suppliers to the Brazilian aircraft producers (van Eeckhaute, 211). 
These ambiguous or diffuse lines of accountability, which result from the need to seek wider support for economic liberalization, complicate the problem of legitimacy. While the AB must be cautious in how it exercises its supranational powers, it needs to find a language to justify its decisions which could persuade a constituency far beyond trade officials and insiders.

\section{EMERGENCE OF ADJUDICATION IN THE GATT: TrADE LAW AND NATIONAL REgUlATION}

The establishment of the $\mathrm{AB}$ was the culmination of a long historical process. From provisions in the GATT to deal with disagreements about trade commitments, a procedure emerged for a form of adjudication of issues that were regarded as essentially technical or non-political matters of interpretation. When the GATT began to move beyond tariffs and quotas to dealing with market access problems caused by regulation ('non-tariff-barriers' NTBs), the disputes became more complex but also potentially more politically contentious. This nevertheless led to a further strengthening of autonomous adjudication as a means of resolving such conflicts, by making adoption of the decisions virtually automatic.

\section{First Steps Towards Adjudication}

The original DS provisions (which still remain part of the GATT agreement within the WTO) grew from the trade negotiation context. They give a member state the right to request consultations if it considers that there has been a 'nullification or impairment' of a benefit, or an objective of the agreement is being impeded. Breaches of WTO rules may result either from failure of another state to comply with an obligation, or even from adoption of a valid measure ('non-violation complaints'). ${ }^{12}$ If the parties concerned cannot resolve the matter, it may be referred to the organization, which should investigate it and make appropriate recommendations to them, or 'give a ruling'. If the matter is considered sufficiently serious, the organization could authorise the suspension of concessions or obligations under the agreement. The procedure can be seen as a means of maintaining the balance of concessions and commitments made under a multilateral trade agreement, since such undertakings may have extensive and unpredictable effects.

The emergence of the GATT Panel procedure, as a quasi-legal form of adjudication, has been carefully chronicled by Robert Hudec $(1975,1993)$. In the very early plenary Sessions of the contracting parties, some complaints about trade restrictions took the form of a request for an interpretation of provisions in the agreement. Initially, these were decided by a ruling from the chair, and then after discussion by the plenary itself. Very quickly, matters unsuitable due to their complexity for plenary debate were referred to working parties. This was a continuation of trade negotiation practice, which therefore aimed at a negotiated solution between the disputants, with the help of neutrals. Where an agreed solution could not be reached, the views of the neutral parties would obviously carry most weight with the plenary, and a key report as early as 1950 was written essentially as an adjudication by the neutrals (Hudec 1975, 70). At the seventh plenary in 1952 there were as many as a dozen complaints on the agenda. These were referred to a single working party, which the chair described as a

\footnotetext{
${ }^{12}$ This originated in a 1933 recommendation that trade agreements should include a general clause requiring consultation regardless of whether the complaint involved a breach of legal obligation. The predominant view was that law was too blunt an instrument to deal with economic questions (Hudec 1975, 21), although some argued for a more legalistic procedure limited to violations of obligations (ibid. 34-6). In practice all but a handful of complaints have concerned alleged violations (Chua; Cottier and Schefer).
} 
Panel. Assisted by the secretariat, new procedures were developed, in which the disputants presented their arguments to the Panel, which then took its decisions and drafted its report in private; the report was then discussed separately with the disputants, before being finalized again in private.

In 1955 the procedure was formalized, on the basis of a Secretariat report, which distinguished between Panels and Working Parties, stressing in particular that Panel members were appointed as individual experts, since their role should be 'to prepare an objective analysis for consideration by the contracting parties, in which the special interests of individual governments are subordinated to the basic objective of applying the Agreement impartially and for the benefit of the contracting parties in general' (Hudec 1975, 297). However, the plenary rejected suggestions to extend the Panel procedure beyond specific bilateral disputes to more general matters, such as consultations with states over their use of balance-of-payments waivers. Although the Secretariat report suggested that also these type of matters might benefit from an 'objective and technical consideration of the issues involved' before a plenary decision, delegates produced various objections, notably the view expressed by the French representative that the Panel report procedure should be used only for 'technical' and not 'political' matters (Hudec 1975, 359 fn 23).

Thus, although the emergence of the Panel procedure was clearly important, it was kept within limited bounds. Hudec's comprehensive survey identifies 53 matters raised between 1948 and 1959 which he classifies as legal, of which some 20 were referred to adjudicative working parties or panels. Hudec, a long-term enthusiast for legal adjudication in the GATT, sees these Panels as embryonic: 'Legal rulings were drafted with an elusive diplomatic vagueness. They often expressed an intuitive sort of law based on shared experiences and unspoken assumptions. Because of policy cohesion within this community, the rate of compliance with these rather vague legal rulings was rather high' (Hudec 1993, 12). In only one case in that period was a Panel report effectively rejected by the Plenary. ${ }^{13}$ Further, there was a clear reluctance to characterize these procedures as a legal adjudication. ${ }^{14}$

Significantly, the Panel procedure was not used for several years following the initial phase, from 1963 to 1970. Those years were a period of major change and adjustment in GATT, caused by (i) the rapid growth in membership which created a 2:1 majority of developing against developed countries, and (ii) the impact of the formation of the EEC as a trade bloc with its common commercial and agricultural policies. The large number of issues and problems these generated were dealt with through major diplomatic negotiations, in particular the Kennedy Round of tariff negotiations (1963-67).

\footnotetext{
${ }^{13}$ See Hudec's Synopsis of Complaints (1993, 417ff), and the more detailed discussion of the early cases in Hudec 1975. The report which was rejected had found that Greece's new ad valorem tariff rate for LP records violated its bound tariff on phonograph records even though this had been a duty based on weight; others, especially developing countries, supported Greece, and an ad valorem tariff rate was eventually agreed (Hudec 1993, 439).

${ }^{14}$ Although the head of the GATT Secretariat, Sir Eric Wyndham White, was himself a lawyer, it appears he strongly opposed the creation of a legal section, which did not occur until 1981, 14 years after his retirement (Hudec 1993, 137-8).
} 


\section{Widening the Agenda and the Trend to Legalization}

The renewed resort to panel procedures in the 1970s, and their increasing importance, can be attributed to the political ramifications, especially for the USA, of the widening agenda of liberalization. The reduction of trade barriers and the strong dollar sucked imports into the US, leading to a deficit on merchandise trade in 1971 and contributing to the ending of the dollar's convertibility into gold. Consequently, US domestic political support for liberalization became much more problematic, requiring much closer involvement in international economic matters of the Congress, for two main reasons. First, rather than simply protecting its powerful domestic economy, the US needed to open up foreign markets. The second, related, issue was the shift of attention to so-called NTBs (non-tariff barriers), which are essentially regulatory differences between states, and therefore raise issues which are as much or more legal as economic, essentially concerning whether the regulatory framework for trade is not only 'free' but also 'fair'. The bulk of GATT complaints concerned NTBs and other 'unfair' trade practices, and the proportion increased as the overall number of complaints grew in the 1980s. ${ }^{15}$ They also became even more complex as consumer concerns and competitive pressures led to a wider range of regulations affecting not only the qualities of goods themselves but also processes and production methods (PPMs), such as environmental protection and animal welfare.

Thus, a significant element in the legalization of the GATT was the relationship of US administrations, responsible for trade relations, and the Congress, the support of which was especially crucial in relation to NTBs. Congressional pressures on the administration to oblige other countries to end unfair trade practices were formalized in the 1974 Trade Act, creating the USTR and the procedures for identification of trade barriers.

Even the EC, which had taken a strong anti-legalist stance in the 1960s, had in 1972 initiated a GATT complaint against one of the Nixon administration's 1971 measures, the DISC (Domestic International Sales Corporation), a form of tax exemption for export sales, which the EC attacked as an export subsidy. The dispute ran for 12 years, until the Congress replaced the DISC with the Foreign Sales Corporation (FSC) (Hudec 1993, ch.5). This dispute brought the Panel procedure to new legal-diplomatic heights, as the US case was managed by the Treasury Department's General Counsel's office, which brought a counterclaim against three European states, and insisted that the claims be heard by a single Panel, including a tax expert. These tactics partly succeeded, in that the GATT Panel balanced its finding against the US with a rather elliptically-worded ruling against the European measures also. Probably intended to secure adoption of the report by consensus, this backfired, since most governments supported the Europeans, and disagreed with the Panel on this point (Hudec 1993, 82-3). The stalemate was only eventually resolved by a compromise under which the reports were accepted subject to an ambiguous 'understanding' (ibid. 91-2), which simply sowed the seed for a subsequent renewal of the dispute. ${ }^{16}$

\footnotetext{
${ }^{15}$ Hudec calculated that of the complaints brought under the GATT, about half concerned NTBs and a further quarter other kinds of 'unfair' trade practices (subsidies and antidumping measures), $75 \%$ in total; the combined proportion rose to $86 \%$ in the 1980 s (Hudec 1993, 338).

16 The FSC, as well as another revised version, have again been successfully challenged by the EU in the WTO (Lubkin), resulting eventually in an authorization to suspend an unprecedented \$5bn worth of trade concessions; although the Congress could not promptly agree acceptable modifications of the corporate tax regime that would be WTO-consistent, only in November 2003 did the EU begin to initiate countermeasures.
} 
The special importance of a quasi-legal adjudicative procedure for dealing with the wide range of regulatory measures having a trade impact was shown by the outcome of the Tokyo trade negotiations Round, which focused especially on NTBs. The Codes governing specific aspects of trade regulation, which were the main outcome of this Round, included a significant tightening of the adjudication procedures. These enabled the negotiators to present the Codes to their legislatures (especially the US Congress) as `valuable new rights obtained in the negotiations', and make more palatable the concessions involved in the Codes themselves. ${ }^{17}$

In the early 1980s GATT members were reluctant to undertake new negotiating initiatives, but there was a sharp growth in legal complaints, ${ }^{18}$ which continued during the Uruguay Round negotiations. An increasing number of these concerned 'linkages' between the GATT trade regime and other regulatory arrangements, including intellectual property (IP) rights, ${ }^{19}$ and consumer protection and food safety regulation. ${ }^{20}$ Most notoriously, environmental protection measures were threatened by two panel rulings in complaints initiated in 1990 and 1992 against the US prohibition of sales of tuna caught by methods which endangered dolphins. Under the GATT's `embedded liberalism' (Ruggie), measures found to be traderestrictive $^{21}$ could nevertheless be justified under the Exceptions clauses of article XX, which required a balancing of the legitimacy of the regulatory purposes against the trade-restrictive effects of the measures. A complaint against another country's regulatory measures on the grounds that it created a trade barrier had the effect of 'disembedding' these national political compromises. It became the task of the GATT Panels to decide the validity of such measures which, although they might entail trade restrictions, were often not explicitly but only $d e$ facto discriminatory, and often originated from otherwise legitimate concerns unrelated to trade.

It seems that Panels found this increasingly difficult within the GATT framework, and considered that article XX was a blunt instrument. This was expressed in the conclusions of the Report of the Panel in the first Tuna-Dolphin dispute, although in typically coded language. ${ }^{22}$ The Panel decided that the US restrictions on sale of tuna caught by non-dolphinfriendly methods could not be justified under the article XX exceptions allowing national

\footnotetext{
${ }^{17}$ Hudec 1993, 55; the italics in the quote are his. However, in relation to the main GATT complaints procedures, few substantive changes were made, although existing practice was formalised in an Agreed Description, and an Understanding on Dispute Settlement.
}

1827 were filed in 1980-82 (Hudec 1993, 139). In 1981 the new DG, Arthur Dunkel, had appointed a Director of Legal Affairs, and by 1983 there was a 3-person legal office.

${ }^{19}$ A 1987 EC complaint against US procedures for seizing IP infringing goods (renewing a Canadian complaint of 1981), and a 1988 complaint by Brazil against US s.301 trade measures attacking Brazil's local working requirements for patents.

${ }^{20}$ Notably, US complaints in 1987 against EC prohibitions of meat imports, in relation to slaughterhouse standards, and then against hormone-treated beef; and in 1989 against Thailand's taxation of cigarettes.

${ }^{21}$ Either because they were discriminatory, or involved quantitative restrictions (interpreted to include a ban) on imports.

${ }^{22}$ Unadopted GATT Panel Report, United States - Restrictions on Imports of Tuna, derestricted 29 November 1991 (reprinted in International Legal Materials (1991) 30: 1594). Note that this Panel was deliberating during the crucial period of the Uruguay Round negotiations in 1991 (Stewart 1993, 2786-93). 
measures to protect animal life or to conserve natural resources, essentially because this would mean imposing US dolphin-protection standards on other countries wishing to export tuna to the US. It considered that this would mean that the GATT 'would then no longer constitute a multilateral framework for trade ... but would provide legal security only in respect of trade between a limited number of [states] with identical internal regulations' (para. 5.27). The Panel suggested that if the GATT were to permit trade restrictions for the purposes of environmental protection, it would have to develop more detailed rules to that end. ${ }^{23}$

The contentious issues raised by these disputes also frequently required domestic legislation to resolve, so making it more difficult for governments to accept the Panel reports (Hudec 1993, 200). A key catalyst stimulating legalization of the DS process was the rather paradoxical policy adopted by the US, resulting once again from the interactions between the administration and the Congress. The difficulties in persuading Congress to pass legislation bringing US law into compliance with GATT rulings were exacerbated by the continued growth of the US trade deficit, which many in the US ascribed to 'unfair trading practices' restricting access by US goods and services into foreign markets. Thus, while the US administration in several cases blocked the setting up of a GATT panel or adoption of a report in a complaint against the USA, it also became more active in threatening or applying trade sanctions under s.301 against others who showed a similar reluctance to respond to US complaints (Hudec 1993, 222ff). Significantly, the 1988 legislation authorizing US participation in the Uruguay Round negotiations also greatly expanded s.301, requiring the USTR to conduct systematic country reviews of market access barriers, and to take action against those found to violate US 'rights'. Paradoxically, therefore, the growing concern in other countries about US unilateralism also generated support for the US negotiating position in the Uruguay Round pressing for a strengthening of adjudication. A key factor in persuading states to accept automaticity in the WTO's DS procedure was the concern of states to curb the use of s.301, which in turn rested on the ability of the US administration to convince the Congress that the Uruguay Round agreements embodied principles of fairness, not only in their substantive market access rules, but crucially also in their DS procedures.

These events formed the backdrop for the Uruguay Round Negotiations, which produced the 26,000-page package of WTO Agreements, by far the longest international treaty ever negotiated. The agreement certainly responded to the plea of the Tuna-Dolphin Panel report, in establishing much more detailed rules for evaluating the validity of national regulations having trade-restrictive effects, including product standards and safety requirements, and intellectual property (although not environmental protection regulations). An important element of the WTO, in some eyes the centrepiece, was the further transformation of the DS procedure into a fully-fledged adjudication system.

\footnotetext{
${ }^{23}$ Ibid., para. 6.3. However, the Uruguay Round negotiators could agree only on inclusion of a brief mention of the 'objective of sustainable development' and protection of the environment, in the preamble to the Agreement establishing the WTO. The Committee on Trade and Environment established April 1994 has produced some lengthy reports but not yet any specific proposals. Not surprisingly, the issues raised in the Tuna-Dolphin dispute resurfaced under the WTO with slight differences in the Shrimp-Turtle case.
} 


\section{WTO ADJUDICATION}

\section{The Legalization of Politics}

Despite the major changes to the DS system in the WTO, it still remains a hybrid of trade diplomacy and legal adjudication. In the WTO, governments decide which matters to refer to adjudication, although as pointed out above this may be influenced by private lobbying or institutionalized domestic procedures for identifying cases. Even so, the timing and handling of cases remains in the hands of governments: for example, the US, Canada and Argentina did not make a formal WTO complaint about the EU regulation of genetically-modified products until May 2003, although their concerns had been expressed both within the WTO and elsewhere for some years. Once a formal complaint is initiated, the procedures must follow a strict timetable designed to produce a decision within 12-15 months. Negotiations may continue during this period, and the dispute may be resolved by agreement or concession, but the complaining state is firmly in the driving seat since it can press for a decision by a Panel. In fact, of the 305 formal complaints initiated in the eight years from 1996 to 2003, 89 had resulted in a published Panel report by mid-2004, and 59 of these had been appealed. ${ }^{24}$

However, adjudicated decisions are only the tip of a much larger iceberg of trade issues and conflicts between states raised in discussions through the various WTO committees, or more widely in global regulatory networks (Picciotto 2003). As with any system of adjudication, an important test of its efficacy is whether its rulings assist parties in resolving potential disputes without resort to adjudication, which is extremely difficult to evaluate (Iida 2004). One approach is to compare the number of national measures which have been questioned in WTO Committees with the number of formal complaints made in relation to such measures. Thus, it has been estimated by Yi that up to August 2003, 89 distinct issues had been raised in the SPS Committee as potentially causing concern under WTO rules, while 13 such matters were dealt with through a formal complaint and consultations, and only three disputes had been taken as far as Panel/AB reports. Karen Alter has provided some anecdotal evidence that the availability of adjudication may have made it easier for states to persuade others to comply with their obligations simply by threatening recourse to the procedure (Alter, 785-6), but she has also cogently argued that the creation of a formalized dispute-settlement system has in some ways exacerbated conflict by allowing conflictual cases to escalate (ibid., 78891). Equally, a government may withdraw a measure in the face of a complaint by a powerful trading partner regardless of its validity. However, the merit of the rules-based system is said to be that it gives some protection to weaker parties.

As in the GATT, Panel members are chosen from states neutral to the issue in question, but they are expected to act as independent experts; however, they are still mainly government

\footnotetext{
${ }^{24}$ Excluding secondary disputes about compliance, but counting separately complaints by different states about the same measures, and by the same state about essentially the same matter. If these are considered a single dispute the total would be some 220; even this overstates the number, since some complaints are made by states as a tactical counter-claim (e.g. Brazil's complaint about aspects of the US Patents code). Details of all the formal complaints are provided on the WTO website; they are also maintained in a helpful analytical database by WorldTradeLaw.net. By comparison, under the GATT between 1948-1995, 131 disputes resulted in Reports. In the first 2-3 years of the WTO almost all Panel decisions were appealed, but this has fallen to about twothirds. For a discussion of the patterns of initiation of formal complaints and of negotiated settlements see Busch and Reinhardt 2002, 2003; Guzman.
} 
officials (Davey 2002, 500). Formally, their task is to assist the Dispute Settlement Body (DSB) by making an 'objective assessment' of the matter referred, especially of the facts, and to make appropriate findings (DSU 11). Their meetings are closed, and documents submitted to them are confidential. The names of the panellists are published when they are appointed but do not appear on the report itself, which is usually a joint one, minority opinions being very rare. ${ }^{25}$ Selection of the panellists is nevertheless an inevitably politicized process, mainly centering on the nationality and background of the panellists and ensuring a geographic balance. ${ }^{26}$

The two most important features, the creation of the Appellate Body and the requirement for automatic adoption of reports, are related, since governments were reluctant to agree automatic adoption without some form of appeal. This was probably due to the difficulties caused by some of the GATT Panel reports which were generally considered misjudged (Steger, 483). It was nevertheless a bold step to give up the national government's veto over adoption of reports, indicating a high degree of trust in the common understandings of the ‘trade community' of the complex normative system they had brought into being.

In the context of the disputes of the 1980s and early 1990s mentioned above, the transfer of powers to the $\mathrm{AB}$ was a much more significant delegation than the decision in 1955 to formalize the GATT panel procedure. It entailed transferring powers of adjudication in relation to disputes that would often be politically controversial, including issues which the political negotiators had been unable to resolve through diplomacy.

Unlike the Panels, the AB is a standing body, composed of seven `persons of recognized authority, with demonstrated expertise in law [and] international trade ... unaffiliated with any government', appointed by the DSB to ensure that it is 'broadly representative' of the WTO membership. ${ }^{27}$ Each appeal is heard by a Division of three members, assigned by rote, so that a judge may be a national of a disputing party; ${ }^{28}$ indeed this often occurs, since the $A B$ has always included nationals both of the US and the EU, which have been parties to the majority of cases.

Thus, a great deal of weight is given to the independence and judicial nature of the AB: 'Members of the Appellate Body do not act as advocates for the national interests of their

\footnotetext{
${ }^{25}$ A notable exception was the Panel Report on US anti-dumping measures against softwood lumber from Canada (WT/DS264, 13 April 2004, section IX), when an unnamed dissenter stood out not only against the majority but in effect against the view taken by the $\mathrm{AB}$ in an earlier case, which has caused sharp debate among trade law cognoscenti (see below).

${ }^{26}$ Citizens of the states party to the dispute may not serve as panellists unless those parties agree, so panellists have been mainly from smaller states (Switzerland, New Zealand, Australia, Brazil, Hong Kong, Canada and Poland): see data on WorldTradeLaw.net.; see also Davey 2002, and the discussion on proposals for a permanent panel body in the March 2003 Journal of International Economic Law.
}

${ }^{27}$ DSU art. 17. Currently they are from Australia, Brazil, Egypt, India, Italy, Japan and the USA. The AB's workload rose from 2 substantive decisions issued in 1996 to 6 in 1997, peaking at 10 in both 1999 and 2000,9 in the next two years and back to 6 in 2003. For further details including biographies see the AB's first Annual Report for $2003 \mathrm{WT} / \mathrm{AB} / 1,7$ May 2004, and for a discussion of the initial establishment and early operation of the $\mathrm{AB}$ see Steger.

${ }^{28}$ This is not specified in the DSU itself, which included only one article establishing the AB, leaving it to draw up its own Working Procedures (Bacchus, 1029). 
home countries; in fact, the judges have displayed levels of integrity and independence that rival those found in the best domestic court systems' (Esserman and Howse, 132). A key factor in cementing this independence has been the collegiality of the AB (Ehlermann 2002). It adopted the GATT practice of seeking to reach decisions by consensus, with remarkable success: in only one case has a member expressed a separate opinion, merely giving differing reasons for agreeing with the majority in one section of the report. It meets together daily in Geneva, using English as a working language, and the Division involved in each case consults the remaining members on the issues involved (Bacchus 2002). Although opinions expressed in the reports are required to be anonymous, the names of the members are stated on the report (unlike the Panels). They are nevertheless considered to be 'faceless judges', perhaps because their hearings and meetings are all closed and confidential (Bacchus, 1024). Until 2004 all were male, with an average age of 64 on appointment. ${ }^{29}$ All have been lawyers, several with experience as domestic court judges or international arbitrators, while others have been diplomats either in trade or other international economic arenas.

\section{The Elusive Promise of Legal Formalism}

The AB's decisions are generally legalistic, although also still rooted in GATT diplomacy. Thus, they are described as 'reports' not judgments, and most of them continue the GATT practice of summarizing at great length the arguments of the parties before reaching the key section giving the analysis and decisions of the $\mathrm{AB}$ itself. Their inordinate length and formal style makes them impenetrable except to the determined specialist. Their tone is juridical, especially in the approach adopted towards the central task of interpretation of the WTO agreements. The $\mathrm{AB}$ has been mindful that under the agreements its role is 'to provide security and predictability to the multilateral trading system' by clarifying the rules, and that only the WTO's political bodies are empowered to provide interpretations of them. ${ }^{30}$ Thus, in an early decision the AB stressed that WTO adjudications are binding only in the particular case. However, it was also careful to state that adopted reports 'form part of the GATT acquis $^{\prime 31}$ since they 'create legitimate expectations among WTO Members', and so should be 'taken into account' in other disputes where they are relevant. ${ }^{32}$ In practice, the $A B$ has set about establishing a coherent body of jurisprudence which lawyers have little difficulty recognizing as a system of precedent (Bhala 1999a, 1999b).

In fact, the delegation of power to adjudicate disputes about the meaning of the WTO agreements inevitably also entails a delegation of authority to interpret them, to the extent that the texts are indeterminate (Trachtman 1999). Most disputes that reach the stage of a Panel report, and even more so one by the $\mathrm{AB}$, are likely to revolve around some textual indeterminacy, if only because there is little point pursuing a claim whose outcome is plain.

\footnotetext{
${ }^{29}$ The youngest by far was the US judge, James Bacchus, who was 46 on his appointment; he was succeeded in December 2003 by Merit Janow, the first woman, also appointed at the age of 46.

30 Art. 3.2 of the DSU firmly states that 'rulings of the DSB cannot add to or diminish the rights and obligations provided in the covered agreements', while the WTO Agreement itself (art. IX.2) specifies that 'The Ministerial Conference and the General Council shall have the exclusive authority to adopt interpretations ... of the ... Agreements', which requires a $75 \%$ majority of states; art.X provides for the adoption of amendments.

${ }^{31}$ This is a term borrowed from EC law, meaning the accumulated rights and obligations of states under the agreements and their accepted interpretations.

${ }^{32}$ Japan - Taxes on Alcoholic Beverages, AB-1996-2, 4 October 1996, section E.
} 
Although the WTO agreements are extensive and detailed, their provisions often remain indeterminate, for two main reasons. Firstly, the agreements may retain ambiguities expressing compromises adopted to paper over policy disagreements between the negotiators which remain to be resolved. It is significant that a substantial number of the early cases taken to the AB have involved issues dating back to the GATT and which were well-known during the Uruguay Round negotiations. These include the US corporate tax treatment of exports, and the EC ban on hormone-treated beef, as well as its bananas regime. Trade negotiators had every opportunity to resolve these long-running concerns in an unambiguous manner.

The second reason flows from the particular characteristic of liberal forms of regulating economic relations, which generally rely on abstract general principles which are meant to guide the actions of private parties in specific cases (McCahery and Picciotto). This is especially the case for WTO rules, which constitute what can be called global metaregulation: rules governing how states should regulate (Morgan). Even as basic a matter as the allocation of a product to a tariff group may be debatable, as seen from an early decision in which the $\mathrm{AB}$ overturned a Panel's view that the EC was wrong to reclassify some types of computer equipment from `automatic data processing' to `telecommunications' equipment. ${ }^{33}$ The general structure of the WTO agreements also entails the evaluation of interacting general rules. Thus, a central principle in the GATT, which also runs through the WTO agreements, is non-discrimination, which prohibits less favourable treatment of 'like products'. This broad obligation is subject in the texts to various conditions and exceptions, so that the evaluation of the legality of a particular measure must consider whether it entails differential treatment of 'like products', and if so whether it may be justified under one of the exceptions.

As Trachtman points out, 'Each step in this analysis has involved a good deal of creativity on the part of the dispute resolution panels and now the $\mathrm{AB}$; in none of these cases is the language of the treaty regarded as determinate' (Trachtmann 1999, 346). Further complexity and uncertainty is created by the interaction of WTO rules with those of other regimes, such as food safety or technical regulations established by international standards organizations. Hence, for example, the sharp conflict over the legality under trade law of regulation of GM foods has been said to be 'submerged in considerable ambiguity and ... uncertainty' not only in the WTO agreements but also the in the 'bewildering labyrinth of rules' which regulators must negotiate (Covelli \& Hohots, 774, 776).

The AB must tread extremely carefully in this regulatory labyrinth to avoid being accused of creative interpretation of the rules. Consequently, it has stressed a literal approach to interpretation. Basing itself on the rules of treaty interpretation in international law, it has emphasized that 'the words of the treaty form the foundation for the interpretive process'. It has relegated to a secondary factor any teleological interpretation by reference to the object and purpose of the treaties, which it considers are to be considered only as part of the context 'also to be taken into account in determining the meaning'. ${ }^{34}$ Emphasizing the importance of

\footnotetext{
${ }^{33}$ European Communities - Customs Classification of Certain Computer Equipment, AB 1998-2; the AB's decision and its reasoning were in turn criticized by Trachtman (1998).

${ }^{34}$ Japan - Taxes on Alcoholic Beverages, AB-1996-2, 4 Oct. 1996, section D. Here, as in many other of its decisions, the $\mathrm{AB}$ has relied on the rules of treaty interpretation set out in arts. 31-2 of the Vienna Convention on the Law of Treaties, following its mandate in art. 3.2 of the DSU to clarify the provisions of the WTO
} 
the words of the texts, it has frequently corrected the reasoning in Panel reports, although rarely altering the overall outcomes. This approach can be regarded as formalist, in that it adopts an essentialist view of the meaning of words, and assumes that the law is a closed and self-referential system of rules. The AB tends to avoid any explicit articulation of the policy implications involved in the inevitable choices presented by the interpretation of texts which are to some extent indeterminate.

The AB's reports deploy this approach with some subtlety, supplementing its emphasis on the words of the texts with some reference to the more general objects and purposes of the agreements, which form the 'context'. This works best when there is a fairly clear textual basis for a preferred purposive interpretation. However, the suspicion that the textual analysis may in practice be used to justify a chosen policy outcome is supported by instances when a plain textual interpretation has been rejected. This can be illustrated by an examination of the reasoning in the AB's Report in the Beef Hormones case. ${ }^{35}$ The AB's decision was that the EC measures were invalid, because they were neither based on an existing international standard nor the result of a proper scientific risk assessment. Thus, although it found for the complainants, the EC was given an opportunity to validate the measures by carrying out a scientific risk assessment, which was certainly a politically astute decision. This is a standard pattern for decisions, since a violation has been found in some $85 \%$ of decisions, but the $A B$ often finds a way to suggest how the national measures might be brought into line with WTO market-access obligations, in order to preserve the state's 'right to regulate'.

The AB approached the issue mainly through a close textual analysis of the WTO's Agreement on Sanitary and Phytosanitary Measures (SPS - the protection of human, animal or plant life or health). I will analyze and contrast two passages in particular to illustrate its methods, and because they provide key justifications of the decision. They concern article 3 of the SPS, which deals with the extent to which there should be harmonization of regulatory measures in this field. Paragraph 1 provides that

'to harmonize [SPS] measures on as wide a basis as possible, Members shall base their [SPS] measures on international standards ... where they exist, except as provided for in this Agreement, and in particular in paragraph 3'.

The $\mathrm{AB}$ focused on the term 'based on', and rejected the interpretation provided by the Panel, which had equated it with the term 'conform to', which is used elsewhere in the Agreement (Report, paras 160-66). Here its textual approach was on solid ground, as the two distinct terms had been used in different articles of the same Agreement, implying there should be a distinction. From this it concluded that a measure might be 'based on' an international standard where, for example, 'only some, not all, of the elements of the standard are incorporated into the measure'. It then confirmed this analysis by referring to the object and purpose of the SPS agreement, and asserted

agreements `in accordance with customary rules of interpretation of public international law'. This is nevertheless a restrictive view of the Vienna Convention's provision that 'A treaty shall be interpreted in good faith in accordance with the ordinary meaning to be given to the terms of the treaty in their context and in light of its object and purpose'.

${ }^{35}$ EC - Measures Concerning Meat and Meat Products (Hormones), AB-1997-4, 16 Jan. 1998. 
'It is clear to us that harmonization of SPS measures of Members on the basis of international standards is projected in the Agreement as a goal, yet to be realised in the future. To read Article 3.1 as requiring Members to harmonize their SPS measures by conforming those measures with international standards, guidelines and recommendations, in the here and now is, in effect, to vest such international standards ... with obligatory force and effect' [emphasis in the original].

Yet SPS Article 3.1 states the purpose of that article as being to 'harmonize [SPS] measures on as wide a basis as possible', and the Panel had seen no deliberate distinction between the term 'based on' rather than 'conform to'. Although it is perfectly possible to make such a distinction, the $\mathrm{AB}$ is using the textual distinction to justify a (perfectly justifiable) preference for a gradual approach to regulatory harmonization.

A few paragraphs later a similar analysis is performed, although this time the text does not support the interpretive choice which the $\mathrm{AB}$ makes in reliance on the 'context'. SPS article 3.3 allows a state to opt for a higher standard of protection than provided in the international standard if there is a scientific justification, or as a consequence of the level of ... protection a Member determines to be appropriate in accordance with the relevant provisions of ... Article 5'. On a textual analysis, the use in this provision of the disjunctive 'or' clearly suggests that a 'scientific justification' and an article 5 determination are alternatives. However, article 5 lays down detailed risk assessment procedures, and the $\mathrm{AB}$ preferred to agree with the Panel that the measures, which the EC argued were based on a 'scientific justification', were invalid because there had not been a proper risk assessment. The AB concedes that this reading in effect negates the textual analysis of the Article, but states that '[i]ts involved and layered language actually leaves us with no choice'. In fact, it is the subsequent consideration of the object and purpose that 'reinforces' the AB's 'belief that compliance with Article 5.1 was intended as a countervailing factor in respect of the right of Members to set their appropriate level of protection'. It is certainly a perfectly acceptable interpretation to read the SPS as requiring any scientific justification to be based on a risk assessment as specified in article 5 , but it cannot be said to flow from a purely textual analysis.

The $\mathrm{AB}$ thus articulates its role as being to reveal and implement the intentions of the negotiators of the agreements through an analysis of the texts. ${ }^{36}$ Although the AB is clearly aware of the policy choices implicit in its interpretations, which have generally been very astute, they are veiled by its emphasis on text and (secondarily) on context.

However, the policy implications are less easily concealed from insiders who have the ability to track the details and trends of decisions. Against the general approbation of the $A B$, it has also encountered some trenchant criticism. This has come especially from trade lawyers,

\footnotetext{
${ }^{36}$ For an analysis which generally approves the AB's textual approach see Lennard. Its cautious view of interpretation has been reinforced by its procedural rulings aimed at guiding panels towards a more legalistic approach, on matters such as the burden of proof, the standing of parties, and the principle of judicial economy (Steger, 487). Its emphasis on this last principle has been explicitly justified by reference to its cautious view of the function of dispute settlement. In the AB's view, WTO adjudication is not meant to `encourage either panels or the Appellate Body to "make law" by clarifying existing provisions of the WTO Agreement outside the context of resolving a particular dispute. A panel need only address those claims which must be addressed in order to resolve the matter in dispute' (US - Measure affecting imports of woven wool shirts and blouses from India, AB-1997-1, p.19).
} 
particularly in the US, who consider that the $\mathrm{AB}$ has been unduly restrictive in its interpretations of the 'trade remedies' permitted under WTO law (anti-dumping and countervailing duties, and emergency safeguards). Indeed one has gone so far as to assert that 'the WTO dispute-settlement system has been far more an exercise in policy-making and far less an exercise in even-handed interpretation of the carefully negotiated language of WTO agreements' (Greenwald, 113). ${ }^{37}$ This critic suggests that the approval of the trade community for the $\mathrm{AB}$ derives from 'a sense that because the decisions, almost without exception, go against countries that maintain trade restraints, they make for good trade policy' (ibid. 114).

A key policy issue is at stake here: the degree of leeway which can be given to governments in relation to their interpretations of what the WTO agreements allow, or in legal terms the 'standard of review' to be applied by the $\mathrm{AB}$ to national measures. The difficulty is that the DSU does not state any general standard of review; uniquely, however, the Anti-Dumping Agreement (ADA, article 17.6) does specify that a panel must uphold a decision by national authorities if it rests on a 'permissible' interpretation, even if that is not the panel's preferred one. This provision was included at the insistence of the US negotiators, but has effectively been neutralized by a refusal of Panels to find any interpretation other than their own to be 'permissible'. Thus, the trade remedy rules have been applied just as strictly as have other exceptions to the WTO's market-access obligations. This is an entirely understandable choice, as the main exponents of anti-dumping and safeguards measures are the large trading blocs, the EU and the US, which resort to them in response to pressures from powerful domestic industry lobbies. Such measures are generally deprecated in the trade community, and even the government authorities responsible for defending them before the WTO are likely to accept a finding of invalidity with good grace. Furthermore, if decisions of national authorities were accorded the degree of deference in anti-dumping cases suggested by article 17.6 , there could be pressures to interpret the other exceptions equally broadly. Such a more deferential or permissive approach to national measures restricting trade would be politically damaging to the WTO's dispute settlement procedures, at least in the trade community.

Nevertheless, the $\mathrm{AB}$ has to some extent been caught in its own trap, since its emphasis on formalist interpretation hinders it from justifying its strict approach to the ADA explicitly in policy terms. Its dilemma illustrates a more general disadvantage to the adoption of a mechanistic and closed approach to the interpretation of legal provisions in international agreements. An important merit of delegating the interpretation of legal obligations on a caseby-case basis to an adjudicative body is to introduce a necessary flexibility which allows incremental adaptation. Otherwise, it has been pointed out that legalization which takes the form of locking states in to detailed and rigid obligations may have a range of negative effects, making it harder to manage the social and political impact of trade agreements, and facilitating mobilization by powerful domestic lobbies to deter liberalization concessions, secure favourable wording, and pressurize governments to insist on a strict application (Goldstein and Martin).

\section{CONCLUSIONS}

The WTO's DS procedures involved a significant shift towards a more legalistic model of adjudication than in the GATT. Although the initial delegation of the task of interpretation to independent adjudication in the GATT was based on the traditional assumption that

\footnotetext{
${ }^{37}$ See also Tarullo; and contra see Davey 2001, Ehlermann 2003.
} 
delegation to a technocratic body should be of non-controversial issues, the strengthening of adjudication in the WTO was in the context of an increase in disputes which could not readily be resolved by negotiation between governments. It developed in response to (i) the greater complexity of issues raised by the increased interaction of trade and related regulatory regimes, and (ii) the need for a stronger basis of legitimacy to convince domestic lobbies and legislators of the need to bring national regulations in line with WTO obligations.

Nevertheless, the legitimacy of WTO rules is still defended on the grounds that they have been agreed by governments. After the organization was shaken by the debacle of the Seattle Ministerial meeting, a speech by the then Director-General Mike Moore concluded as follows:

'People do not want a world government, and we do not aspire to be one. At the WTO, governments decide, not us. ... But people do want global rules. If the WTO did not exist, people would be crying out for a forum where governments could negotiate rules, ratified by national parliaments, that promote freer trade and provide a transparent and predictable framework for business. And they would be crying out for a mechanism that helps governments avoid coming to blows over trade disputes. That is what the WTO is. We do not lay down the law. We uphold the rule of law. The alternative is the law of the jungle, where might makes right and the little guy doesn't get a look in.'

It is therefore not surprising that the $\mathrm{AB}$ should deploy legalistic language and a formalist emphasis on the objective application the words of the agreements to placate the broader public, while hoping to convince the specialists in trade and economic regulation through shared understandings of the interpretations which are desirable to achieve the goals of free trade. Unfortunately, it risks failing to convince insiders, as has already occurred in relation to the trade remedies issue discussed above, while doing little to reach out to persuade a broader constituency of the fairness of WTO rules.

The AB's caution is also due to its uncertainty about its accountability, expressed as a concern to avoid accusations that it has exceeded its mandate through judicial activism. In this respect it has been contrasted with the jurisprudence of the European Court of Justice, which 'often show a confidence and a willingness to take an activist approach (often to deal with an impasse at the EU political level) [which] demonstrates the difference between the ECJ's broad "constitution" and the more narrowly confined one of the Appellate Body' (Lennard, 44).

The importance to the WTO as a whole that the decisions of the DS system should be widely accepted as legitimate suggests further moves towards its juridification. Certainly, commentators have suggested reforms which would turn it into a full-blown judicial body, with standing Panels acting essentially as courts of first instance, hearings in public, and open acceptance of submissions by non-governmental organizations. ${ }^{38}$ Significantly, however, the proposals put forward by governments have been much more modest. ${ }^{39}$

\footnotetext{
${ }^{38}$ See e.g. Weiler; Davey 2002, 2003. The AB has taken a cautious step towards this last, by stating that such amicus curiae briefs may be accepted if they are 'pertinent and useful' (EC-Trade Description of Sardines AB-2002-3, para. 160). This met with hostility from many governments, and it was stressed in the DSB that the $\mathrm{AB}$ should not adopt any changes to its working procedures without consulting the DSB (DSB Minutes of 24
} 
A shift towards greater procedural juridification would extend the accountability of the DS system beyond governments, and could encourage the $\mathrm{AB}$ to address its decisions more overtly to a broader public. This would entail a much more explicit articulation of the values underlying the WTO, and in particular the interaction of its market-opening liberalization principles with regulations embodying socially-constructed preferences such as health and environmental protection. This has certainly been advocated by some (Bronckers; Alter). Others have taken a different tack, and have advocated the 'constitutionalization' of the WTO based on individual human rights (Petersmann 2002, 2003). This view has been criticized, both as involving a very narrow concept of human rights and its 'takeover' by trade law (Alston), and as providing only a limited basis for balancing the aims of market liberalization against other social preferences embodied in regulation (Picciotto 2003). ${ }^{40}$

Thus, the $\mathrm{AB}$ is caught on the horns of an institutional dilemma. It feels restrained from expressing in more open terms the policy considerations which underpin its interpretations, for fear of usurping the political legitimacy of the governments to which it is primarily accountable. They in turn are motivated by a reluctance not so much to concede power as to admit to their domestic constituencies how much power has already been transferred to supranational instances such as the AB. Until the political system faces up to this, it will be difficult for global governance institutions such as the AB to develop in ways that are more directly accountable to a global public, and hence to contribute to new forms of democratic deliberation appropriate for multi-level governance (Picciotto 2001; Joerges and Neyer).

\section{BIBLIOGRAPHY}

Abbott, K., R. O. Keohane, A. Moravcsik, A.-M. Slaughter, D. Snidal 2000. The Concept of Legalization. International Organization 54: 401-419.

Abbott, K. W. and D. Snidal. 2000. Hard and Soft Law in International Governance. International Organization 54: 421-56.

Alston, Philip. 2002. Resisting the Merger and Acquisition of Human Rights by Trade Law: A Reply to Petersmann. European Journal of International Law 13: 815-844.

Alter, K. J. 2003. Resolving or exacerbating disputes? The WTO's new dispute resolution system. International Affairs 79: 783-800.

Bacchus, J. 2002. Table Talk: Around the Table of the Appellate Body of the World Trade Organization. Vanderbilt Journal of Transnational Law 35: 1021-1039.

July 2000, WT/DSB/M/84, para. 86). The AB has diplomatically said in most cases that it has not taken such briefs into account as they have not been helpful.

${ }^{39}$ See Report by the DSB Chairman to the Trade Negotiations Committee, TN/DS/9, 6 June 2003.

${ }^{40}$ However, it has also been pointed out that a form of constitutionalization is already taking place through the AB's `judicial norm-generation', using devices such as rational relationship testing, proportionality, and less restrictive means, to delineate both the legitimate scope of national state regulatory powers impinging on trade, as well as the relationship of the trade régime to related international regulatory regimes (Cass; see also Picciotto, 2000) 
Bhala, R. 1999a. The Myth about Stare Decisis and International Trade Law (Part one of a Trilogy). American University International Law Review 14: 845-956.

Bhala, R. 1999b. The Precedent Setters: De Facto Stare Decisis in WTO Adjudication (Part Two of a Trilogy). Journal of Transnational Law \& Policy 9: 1-151.

Bronckers, M. 2001. More power to the WTO? Journal of International Economic Law 4: 41-65.

Busch, M. L. and E. Reinhardt. 2002. Testing international trade law: Empirical studies of GATT/WTO dispute settlement. In D. L. M. Kennedy and J. D. Southwick, eds., The Political Economy of International Trade Law. Essays in Honor of Robert E. Hudec. Cambridge, CUP: 457-81.

Busch, M. L. and E. Reinhardt. 2003. Developing countries and General Agreement on Tariffs and Trade World Trade Organization dispute settlement. Journal of World Trade 37: 719-735.

Cass, D. Z. 2001. The 'Constitutionalization' of International Trade Law: Judicial Normgeneration as the Engine of Constitutional Development in International Trade. European Journal of International Law 12: 239.

Charnovitz, S. 2001. Rethinking Trade Sanctions. American Journal of International Law 95: 792-832.

Chua, A. T. L. 1998. Reasonable Expectations and Non-Violation Complaints in GATT/WTO Jurisprudence. Journal of World Trade 32: 27-50.

Covelli, N. and V. Hohots 2003. The Health Regulation of Biotech Foods under the WTO Agreements. Journal of International Economic Law 6: 773-795.

Dam, K. W. 1970. The GATT - Law and Economic Organization. Chicago, University of Chicago Press.

Davey, W. J. 2001. Has the WTO dispute settlement system exceeded its authority? A consideration of deference shown by the system to member government decisions and its use of issue-avoidance techniques. Journal of International Economic Law 4: 79110.

Davey, W. J. 2002. A permanent panel body for WTO dispute settlement: desirable or practical? In D. L. M. Kennedy and J. D. Southwick, eds., The Political Economy of International Trade Law. Essays in Honor of Robert E. Hudec. Cambridge, CUP.

Davey, W. J. 2003. The Case for a Permanent Panel Body. Journal of International Economic Law 6: 177-86.

Dryzek, J. S. 1990. Discursive Democracy. Cambridge, Cambridge University Press.

Dryzek, J. S. 1999. Transnational Democracy. Journal of Political Philosophy 7: 30-51.

Ehlermann, C.-D. 2002. Six Years on the Bench of the 'World Trade Court'. Some Personal Experiences as a Member of the Appellate Body of the WTO. Journal of World Trade 36: 605-39. 
Ehlermann, C.-D. 2003. Reflections on the Appellate Body of the WTO. Journal of International Economic Law 6: 695-708.

Esserman, S. and R. Howse 2003. The WTO On Trial. Foreign Affairs 82: 130-140.

Finnemore, M. and S. J. Toope 2001. Alternatives To 'Legalization': Richer Views Of Law And Politics. International Organization 55: 743-58.

Fuller, L. L. 1958. Positivism and Fidelity to Law--A Reply to Professor Hart. Harvard Law Review 71: 630 .

Goldstein, J., M. Kahler, R. O. Keohane and A.-M. Slaughter, eds. 2001. Legalization and World Politics. Cambridge, Mass., MIT Press. [Publication in book form of a Special Issue of International Organization 2000; citations to the individual chapters are to the articles in the journal.]

Greenwald, J. 2003. WTO dispute settlement: An exercise in trade law legislation?" Journal of International Economic Law 6: 113-124.

Guzman, A. 2003. The Political Economy of Litigation and Settlement at the WTO. Berkeley Olin Program in Law \& Economics, Working Paper Series.

Hart, H. L. A. 1958. Positivism and the Separation of Law and Morals. Harvard Law Review 71: 593.

Hudec, R. E. 1975. The GATT Legal System and World Trade Diplomacy. New York, Praeger.

Hudec, R. 1993. Enforcing International Trade Law. Evolution of the GATT DisputeSettlement System. London, Butterworths.

Joerges, C. and J. Neyer. 2003. Politics, risk management, World Trade Organization governance and the limits of legalisation. Science and Public Policy 30: 219-225.

Kooiman, J., Ed. 1993. Modern Governance. New Government-Society Interactions. London, Sage.

Lennard, M. 2002. Navigating by the Stars: Interpreting the WTO Agreements. Journal of International Economic Law 5: 17-89.

Lubkin, G. 2002. The end of extraterritorial income exclusion? The W.T.O. Appellate decision and its consequences. Tax Management International Journal 31: 254.

Manin, B. 1997. The Principles of Representative Government. Cambridge, CUP.

Matsushita, M., Thomas J. Schoenbaum, Petros C. Mavroidis. 2003. The World Trade Organization. Law, Practice, and Policy. Oxford, OUP.

McCahery, J. and S. Picciotto 1995. Creative Lawyering and the Dynamics of Business Regulation, in Y. Dezalay and D. Sugarman, eds., Professional Competition and Professional Power. Lawyers, Accountants and the Social Construction of Markets, Routledge, London. 
McGinnis, J. O. and M. L. Movsesian 2000. The World Trade Constitution. Harvard Law Review 114: 512-605.

Moore, M. 2000. The Backlash against Globalization? Speech delivered to the Liberal International, $26^{\text {th }}$ October.

Morgan, B. 2003. The Economization of Politics: Meta-Regulation as a Form of Nonjudicial Legality. Social \& Legal Studies 12: 489-523.

Petersmann, E.-U. 2002. Constitutionalism and WTO law: from a state-centered approach towards a human rights approach in international economic law. $N$ D. L. M. Kennedy and J. D. Southwick, eds., The Political Economy of International Trade Law. Essays in Honor of Robert E. Hudec. Cambridge, CUP.

Petersmann, E.-U. 2003. Human Rights and the Law of the World Trade Organization. Journal of World Trade 37: 241-81.

Picciotto, S. 1997. Fragmented States and International Rules of Law. Social and Legal Studies 6: 259-279.

Picciotto, S. 2001. Democratizing Globalism. In D. Drache, ed., The Market or the Public Domain? Global Governance and the Asymmetry of Power. London, Routledge.

Picciotto, S. 2003. Private Rights vs Public Standards in the WTO. Review of International Political Economy 10: 377-405.

Pierre, J., Ed. 2000. Debating Governance. Oxford, OUP.

Ruggie, J. G. 1982. International Regimes, Transactions and Change: Embedded Liberalism in the Postwar Economic Order. International Organization 36: 379-415.

Shaffer, G. C. 2003. Defending Interests: Public-Private Parternships in WTO Litigation. Washington DC, Brookings Institution Press.

Shoyer, A. W. 2003. Panel Selection in WTO Dispute Settlement Proceedings. Journal of International Economic Law 6: 203-9.

Shapren, A. J. 2003. Nafta Chapter 11: A Step Forward In International Trade Law Or A Step Backward For Democracy? Temple International and Comparative Law Journal 17: 323-350.

Shelton, D., Ed. 2000. Commitment and Compliance. The Role of Non-Binding Norms in the International Legal System. Oxford, OUP.

Steger, D. P. 2002. The Appellate Body and its contribution to WTO dispute settlement. In D. L. M. Kennedy and J. D. Southwick, eds., The Political Economy of International Trade Law. Essays in Honor of Robert E. Hudec. Cambridge, CUP.

Stewart, T. P., Ed. 1993. The GATT Uruguay Round. A Negotiating History. Deventer, Kluwer. 
Tarullo, Daniel K. 2002. The Hidden Costs Of International Dispute Settlement: WTO Review Of Domestic Anti-Dumping Decisions. Law and Policy in International Business 34: 109.

Tollefson, C. 2002. Games Without Frontiers: Investor Claims And Citizen Submissions Under The Nafta Regime. Yale Journal of International Law 27: 141.

Trachtman, Joel P. 1998. Case-Note: EC - Customs Classification of Certain Computer Equipment. European Journal of International Law 9: 551.

Trachtman, Joel P. 1999. The Domain of WTO Dispute-Resolution. Harvard International Law Journal 40: 333-377.

Weiler, J. H. H. 2001. The rule of lawyers and the ethos of diplomats - Reflections on the internal and external legitimacy of WTO dispute settlement. Journal of World Trade 35: 191-207.

Yi, Yun-Jung 2004. Standards and Science in Trade Regulation in the Global Age: A Critique of the WTO SPS Agreement in relation to Public Health and Safety Concerns. Ph.D. Thesis, Lancaster University. 